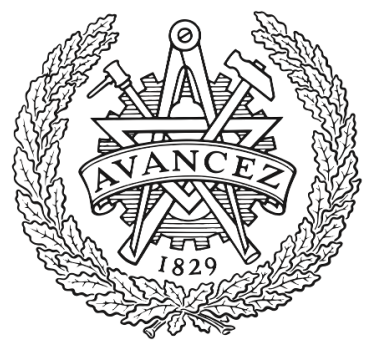

CHALMERS

UNIVERSITY OF TECHNOLOGY

\title{
The influence of different factors on the dual atmosphere effect observed for AISI 441 interconnects used in solid oxide fuel cells
}

Downloaded from: https://research.chalmers.se, 2023-04-26 15:16 UTC

Citation for the original published paper (version of record):

Goebel, C., Bo, C., Svensson, J. et al (2019). The influence of different factors on the dual atmosphere effect observed for AISI 441

interconnects used in solid oxide fuel cells. ECS Transactions, 91(1): 2261-2266.

http://dx.doi.org/10.1149/09101.2261ecst

N.B. When citing this work, cite the original published paper. 


\title{
The Influence of Different Factors on the Dual Atmosphere Effect Observed for AISI 441 Interconnects Used in Solid Oxide Fuel Cells
}

\author{
Claudia Goebel, Caterina Bo, Jan-Erik Svensson, Jan Froitzheim \\ Energy and Materials, Chalmers University of Technology, Kemivägen 10, 41296 \\ Gothenburg, Sweden
}

\begin{abstract}
Interconnects used in solid oxide fuel cells are subjected to dual atmosphere corrosion at $600^{\circ} \mathrm{C}$. In this work we show that the dual atmosphere effect is dependent on the thickness of the steel sheet. For this AISI 441 with varying thicknesses was exposed to dual atmosphere at $600{ }^{\circ} \mathrm{C}$ for $336 \mathrm{~h}$. Before and after exposure photographs were taken to analyze the progress of corrosion on the air-facing side of the steel samples. Additionally, scanning electron microscopy and energy dispersive $x$-ray diffraction (SEM/EDX) analysis was conducted on all exposed samples. It was found that thinner samples showed increased breakaway oxidation than thicker samples.
\end{abstract}

\section{Introduction}

Solid oxide fuel cells can convert chemical energy into electrical energy without combustion and are therefore a promising future technology with clean emissions $(1,2)$. However, before wide-spread commercialization can be achieved key factors such as the high cost and the limited life-time of the solid oxide fuel cell technology must be addressed. Both factors are heavily influenced by the interconnect, which connects separate fuel cells to form a fuel cell stack (3). Besides being a large cost factor to the overall stack the interconnect also suffers from severe corrosion under the conditions present in the SOFC, i.e. high temperatures between 600 and $900{ }^{\circ} \mathrm{C}$ and oxidizing and reducing atmospheres $(4,5)$.

Until the early 2000s the typical operating temperatures of solid oxide fuel cells were above $800^{\circ} \mathrm{C}$, however a lowering of the operating temperatures to 550 to $700{ }^{\circ} \mathrm{C}$ can be observed in research as well as for fuel cell companies (6). This decrease in temperature is especially interesting, because it is expected to allow the use of cheaper materials, especially for the interconnect. As mentioned earlier, the interconnect is a major cost factor for solid oxide fuel cells, especially when specialized steels, such as Crofer 22APU, are being used. This cost can be reduced by a factor of 10 , if, instead, commercially available steels, such as AISI 441, can be utilized $(7,8)$. However, the transition from $800^{\circ} \mathrm{C}$ to $600^{\circ} \mathrm{C}$ has led to other difficulties. For example, Alnegren et al. have reported that especially at $600^{\circ} \mathrm{C}$ the so-called dual atmosphere effect becomes more prominent than at $800^{\circ} \mathrm{C}(9,10)$.

The dual atmosphere effect occurs when ferritic stainless steels, such as AISI 441, are exposed to air on one side and to hydrogen on the other side. Under these conditions increased corrosion is found on the air-facing side compared to if the steel was only exposed in single, i.e. air atmosphere (9-12). There have been so far many theories on why the dual atmosphere is more detrimental than single atmosphere, but thus far none of these theories have been confirmed. What is, however, agreed upon, by different researchers in the field, is that hydrogen is the culprit (13-15). This is also supported by our recent studies on the effect that pre-oxidation has on the dual 
atmosphere effect $(16,17)$. Here we showed that the pre-oxidation layer on the fuelfacing side is more important as a useful mitigation strategy against the dual atmosphere effect than the pre-oxidation layer on the air-facing side. This suggests that the preoxidation layer can mitigate the hydrogen inward diffusion. This is in line with studies by Kurokawa et al. $(14,15)$, who have shown that the hydrogen permeation through steel is much faster than the hydrogen permeation through an oxide layer.

In the present work we aim to clarify if the hydrogen diffusion through the steel is sufficiently fast enough to disregard it for interconnect applications. Thus AISI 441 with different thickness ranging from $0.1 \mathrm{~mm}$ to $0.7 \mathrm{~mm}$ were exposed to dual atmosphere at $600{ }^{\circ} \mathrm{C}$ for $500 \mathrm{~h}$.

\section{Experimental}

AISI 441 with a thickness of $1 \mathrm{~mm}$ and a thickness of $0.2 \mathrm{~mm}$ were used for the conducted experiment. The material composition can be found in Table I.

TABLE I. Material composition in weight\% of AISI 441.

\begin{tabular}{|c|c|c|c|c|c|c|c|c|c|c|c|c|}
\hline & $\mathrm{Fe}$ & $\mathrm{Cr}$ & Mn & Si & $\mathrm{Ti}$ & $\mathbf{N b}$ & $\mathbf{N i}$ & C & S & $\mathbf{N}$ & $\mathbf{P}$ & Mo \\
\hline $\begin{array}{l}\text { AISI } \\
441\end{array}$ & Bal. & 17.50 & 0.28 & 0.42 & 0.13 & 0.38 & 0.21 & 0.018 & 0.001 & 0.015 & 0.024 & 0.025 \\
\hline
\end{tabular}

All samples were punched out of steel sheets into circular samples with a diameter of $21 \mathrm{~mm}$. Coupons of the $1 \mathrm{~mm}$ thick AISI 441 material were then ground to 4 different thicknesses, $0.1 \mathrm{~mm}, 0.2 \mathrm{~mm}, 0.5 \mathrm{~mm}$ and $0.7 \mathrm{~mm}$ with grit P1200. The $0.2 \mathrm{~mm}$ thick AISI 441 batch was not ground and acted as a reference, thus this sample will be called the as-received sample in the present work. All coupons were ultrasonically cleaned in ethanol and acetone before pre-oxidizing them for $20 \mathrm{~min}$ at $800^{\circ} \mathrm{C}$ in an air flow rate of $280 \mathrm{sml} \mathrm{min}-1$ and $3 \%$ water vapor. The pre-oxidation length was chosen because previous studies have shown that shorter pre-oxidation times result in accelerated corrosion in dual atmosphere $(16,17)$. The other pre-oxidation parameters, i.e. temperature and atmosphere, were chosen to resemble a stack sintering step.

Dual atmosphere exposures were conducted using a previously described experimental setup $(9,12,18,19)$. Air with $3 \% \mathrm{H}_{2} \mathrm{O}$ vapor was employed to simulate the air atmosphere in the SOFC and to ensure kinetically controlled Cr-evaporation a flow rate of $8800 \mathrm{sml} \mathrm{min}{ }^{-1}$ was set. For the fuel-side $5 \% \mathrm{H}_{2}$-Ar with a $\mathrm{H}_{2} \mathrm{O}$ vapor content of $3 \%$ and a flow rate of $100 \mathrm{sml} \mathrm{min}^{-1}$ was used. The dual atmosphere exposure was carried out for $336 \mathrm{~h}$ at $600^{\circ} \mathrm{C}$ and it was interrupted after $168 \mathrm{~h}$ to visualize the corrosion progress by photography. Heating and cooling down rates were set to $1^{\circ} \mathrm{C} / \mathrm{min}$. A second experimental run confirmed the results of the first dual atmosphere exposure.

After exposure all samples were photographed and analyzed further by scanning electron microscopy (SEM) and energy dispersive x-ray (EDX) diffraction using a Zeiss LEO Ultra 55 FE-SEM equipped with an Oxford Inca EDX System.

\section{Results and Discussion}

The photographs taken of AISI 441 samples before and after $336 \mathrm{~h}$ of dual atmosphere exposure at $600{ }^{\circ} \mathrm{C}$ are depicted in Figure 1. The thinner ground samples showed increased breakaway corrosion compared to thicker samples. Especially the 
$0.1 \mathrm{~mm}$ thick ground sample showed a high coverage of breakaway oxidation, whereas only isolated nodules were found on $0.7 \mathrm{~mm}$ thick ground AISI 441 . Thus, a correlation was found for all ground samples between the sample thickness and the extent of breakaway corrosion visible on the sample surface can be found.

The extent of breakaway oxidation of the $0.2 \mathrm{~mm}$ thick ground sample and the asreceived sample differ a lot, with the latter being nearly completely covered by breakaway oxidation. This is in agreement with earlier published results that indicate grinding improves the resistance against the dual atmosphere effect (16).

\begin{tabular}{|c|c|c|c|c|c|}
\hline & $\begin{array}{l}\text { AISI } 441 \\
\text { Ground } \\
0.7 \mathrm{~mm}\end{array}$ & $\begin{array}{l}\text { AISI } 441 \\
\text { Ground } \\
0.5 \mathrm{~mm}\end{array}$ & $\begin{array}{l}\text { AISI } 441 \\
\text { Ground } \\
0.2 \mathrm{~mm}\end{array}$ & $\begin{array}{l}\text { AISI } 441 \\
\text { Ground } \\
0.1 \mathrm{~mm}\end{array}$ & $\begin{array}{c}\text { AISI } 441 \\
\text { As-received } \\
0.2 \mathrm{~mm}\end{array}$ \\
\hline $\begin{array}{l}\text { Before } \\
\text { exposure }\end{array}$ & & & & & \\
\hline $\begin{array}{c}\text { After } \\
\text { exposure }\end{array}$ & & & & & \\
\hline
\end{tabular}

Figure 1. Photographs of the air-facing side of AISI 441, which was discontinuously exposed to dual atmosphere for $336 \mathrm{~h}$ at $600^{\circ} \mathrm{C}$. Prior to dual atmosphere exposure all the samples, except for the as-received sample, were ground from a $1 \mathrm{~mm}$ thick AISI 441 steel sheet to the desired thickness with grit P1200.

Micrographs of SEM top-view analysis for dual atmosphere exposed samples are shown in Figure 2 and they corroborate the results of the visual inspection in Figure 1. EDX confirmed that iron-rich nodules had formed to varying extent for all ground AISI 441 samples with the remaining surface still being covered by a protective oxide. With a decrease in thickness not only more iron-rich nodules had formed on the sample surface, but also these nodules were much larger in size. Except for the edges, the as-received AISI 441 is completely covered with an iron rich oxide layer. From previous studies (9, $10,16)$ it can be assumed that all the iron-rich oxide formed on the sample surface is outward growing $\mathrm{Fe}_{2} \mathrm{O}_{3}$ with an inward growing mixed $(\mathrm{Cr}, \mathrm{Fe})_{3} \mathrm{O}_{4}$ beneath it. 


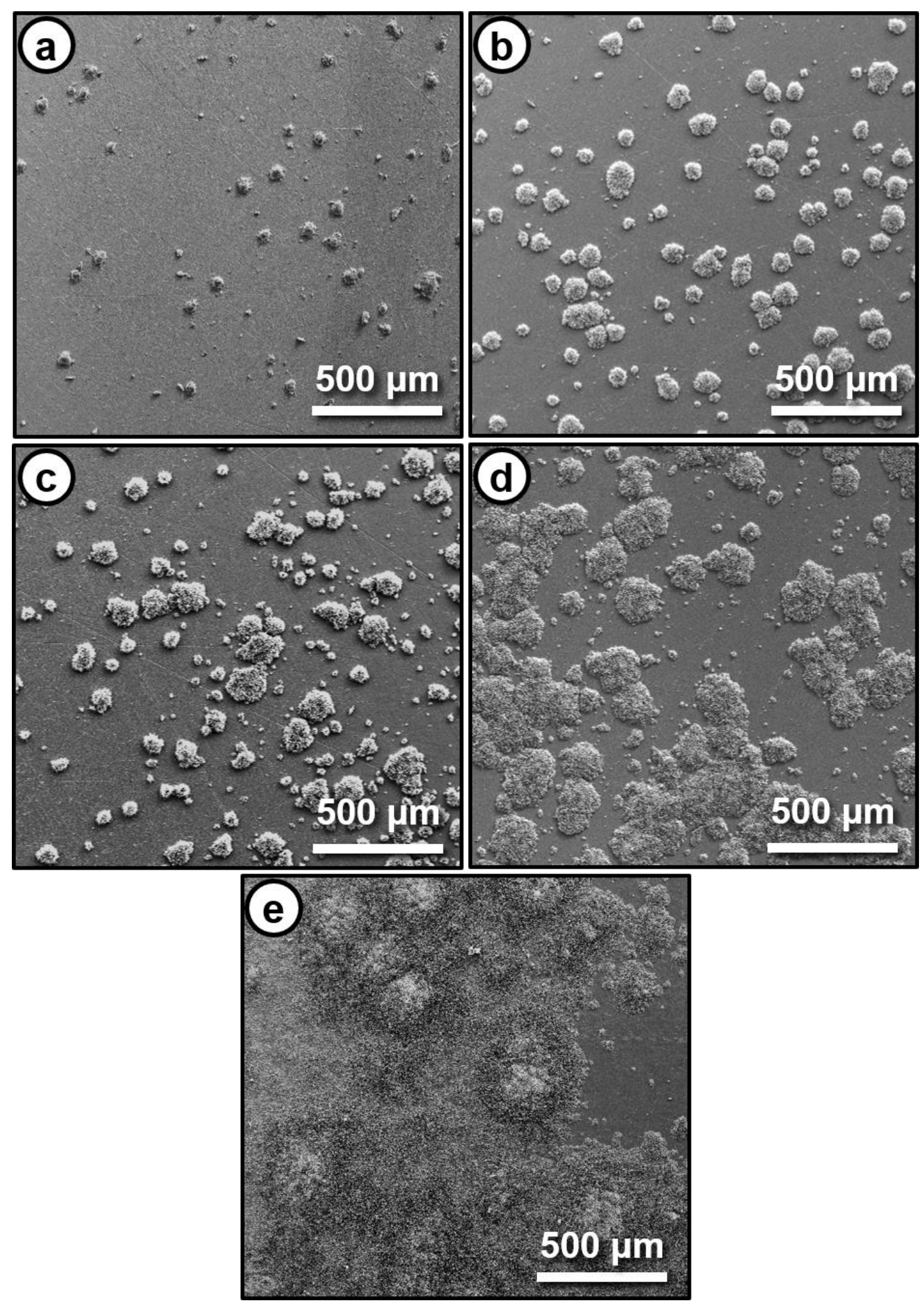

Figure 2. SEM micrographs of the air-facing side of AISI 441, which was discontinuously exposed to dual atmosphere for $336 \mathrm{~h}$ at $600^{\circ} \mathrm{C}$. Prior to dual atmosphere exposure all the samples were ground with grit P1200 from a $1 \mathrm{~mm}$ thick AISI 441 steel sheet to different thicknesses $0.7 \mathrm{~mm}$ (a), $0.5 \mathrm{~mm}$ (b), $0.2 \mathrm{~mm}$ (c), and $0.1 \mathrm{~mm}$ (d), except for the as-received sample with a thickness of $0.2 \mathrm{~mm}(\mathrm{e})$, which was not ground.

The results indicate that the sample thickness does matter for corrosion resistance in dual atmosphere and thus thicker AISI 441 can withstand the detrimental effect of the 
dual atmosphere for longer. It is important to note that this effect is not due to the $\mathrm{Cr}$ depletion of the bulk material, because the $\mathrm{Cr}$ levels of the bulk material are not significantly affected by the chosen pre-oxidation parameters and the ensuing dual atmosphere exposure is carried out at $600{ }^{\circ} \mathrm{C}$ and should therefore not lead to a high $\mathrm{Cr}$ consumption. Instead the reason for the thickness effect is assumed to be that, despite the rapid hydrogen diffusion through steel, the thicker steel sheet can reduce hydrogen permeation. Kurokawa et al. $(14,15)$ estimated the hydrogen permeation coefficient in iron to be approximately 10000 times greater than in $\mathrm{Cr}_{2} \mathrm{O}_{3}$. The metal to oxide thickness ratio in the present work is estimated to be roughly 2000 for the thinnest metal sheet and 14000 for the thickest. This matches well with the observation that the oxide layer acts as the main hydrogen barrier but the permeation through the steel is not entirely negligible.

\section{Conclusion}

The present work showed that the thickness of AISI 441 matters for the dual atmosphere effect. Thus, thicker AISI 441 samples can withstand the dual atmosphere effect for increased time lengths than thinner AISI 441 samples. It was also shown that grinding the surface of AISI 441 increases the corrosion resistance of this steel against the dual atmosphere effect.

\section{Acknowledgments}

The authors are grateful for funding by the Swedish Energy Agency (grant 2015009652), the FFI program, as well as the Swedish High Temperature Corrosion Centre. This work was performed in part at the Chalmers Material Analysis Laboratory, CMAL.

\section{References}

1. A. B. Stambouli and E. Traversa, Renew. Sust. Energ. Rev., 6, 433 (2002).

2. M. Powell, K. Meinhardt, V. Sprenkle, L. Chick and G. McVay, J. Power Sources, 205, 377 (2012).

3. J. W. Fergus, Mater. Sci. Eng., A, 397, 271 (2005).

4. L. Niewolak, F. Tietz and W. J. Quadakkers, in High-temperature solid oxide fuel cells for the 21st century: fundamentals, design and applications, 2 ed. (2015).

5. W. J. Quadakkers, J. Piron-Abellan, V. Shemet and L. Singheiser, Mater. High Temp., 20, 115 (2003).

6. J. P. P. Huijsmans, F. P. F. van Berkel and G. M. Christie, J. Power Sources, 71, 107 (1998).

7. L. Niewolak, E. Wessel, L. Singheiser and W. J. Quadakkers, J. Power Sources, 195, 7600 (2010).

8. J. Fergus and Y. Zhao, ECS Transactions, 35, 2447 (2011).

9. P. Alnegren, M. Sattari, J.-E. Svensson and J. Froitzheim, J. Power Sources, 301, 170 (2016).

10.P. Alnegren, M. Sattari, J.-E. Svensson and J. Froitzheim, J. Power Sources, 392, 129 (2018).

11.Z. Yang, M. S. Walker, P. Singh, J. W. Stevenson and T. Norby, J. Electrochem. Soc., 151, B669 (2004).

12.P. Gannon and R. Amendola, JOM, 64, 1470 (2012).

13. A. W. Bredvei Skilbred and R. Haugsrud, Int. J. Hydrogen Energy, 37, 8095 (2012). 
14. H. Kurokawa, K. Kawamura and T. Maruyama, Solid State Ionics, 168, 13 (2004). 15. H. Kurokawa, Y. Oyama, K. Kawamura and T. Maruyama, J. Electrochem. Soc., 151, A1264 (2004).

16.C. Goebel, P. Alnegren, R. Faust, J.-E. Svensson and J. Froitzheim, Int. J. Hydrogen Energy, 43, 14665 (2018).

17.C. Goebel, P. Alnegren, R. L. Faust, J.-E. Svensson and J. Froitzheim, ECS Transactions, 78, 1559 (2017).

18.G. R. Holcomb, M. Ziomek-Moroz, S. D. Cramer, B. S. Covino and S. J. Bullard, J. Mater. Eng. Perform., 15, 404 (2006).

19. J. Rufner, P. Gannon, P. White, M. Deibert, S. Teintze, R. Smith and H. Chen, Int. J. Hydrogen Energy, 33, 1392 (2008). 